\title{
A General Approach to the Balance of Payments and Exchange Rates
}

\author{
Norman C. Miller*
}

\section{Introduction and Literature Review}

\section{1.}

The objective in this paper is to develop a general framework for analyzing the balance of payments and/or exchange rates. This is done by deriving Walrasian types of identities for an open economy that tell us what must be true in order for the balance of payments to be nonzero, or, equivalently within a flexible rate world, what must occur within the general equilibrium system in order for the exchange rate to appreciate or depreciate. These concomittant events refer to the fact (to be proven below) that one or more domestic markets must be initially out of equilibrium in order for the balance of payments to be non-zero, or for the exchange rate to vary. This fundamental conclusion has important implications with regard to (a) the appropriate modeling of an open economy; (b) the effects of economic growth on the balance of payments or exchange rate; (c) how monetary and fiscal policy affect the balance of payments or exchange rate; and (d) how and why alternative adjustment policies may or may not be appropriate, depending on which domestic market is the "culprit" in creating a payments imbalance.

\section{2.}

The well known foreign exchange market approach to the balance of payments and exchange rate determination has always been correctly presented as a partial equilibrium approach. In the 1950 s and 1960 s, the foreign exchange market or "elasticities" approach was replaced by and then synthesized with the Keynesian income-absorption model by

* Lange Professor of Economics, Miami University, U.S.A.

The author wishes to thank Polly Allen, Jim Cassing, Steve Husted, Bob Flood, Brian Ross, Mark Rush, and Leyland Yeager for comments on earlier drafts of this work. 
Alexander [1959] and others. Some version of this still appears in most money and banking, intermediate macroeconomics, and international finance textbooks, via the $I S, L M$, and balance of payments, $B P$, curves.

In such models, the interest rate and income are determined at the intersection of $I S$ and $L M$. The sign and magnitude of the balance of payments is determined according to whether the economy lies above or below its $B P$ curve. We refer to such models as the Mundell-Fleming or Keynesian models of the balance of payments, KBP. ${ }^{1}$ In the flexible exchange rate versions of these models, the balance of payments is constrained to zero, and the model is solved for income, the interest rate, and the value of the exchange rate. We call such models the Keynesian exchange rate models, KER, because they are embedded in the traditional Keynesian $I S, L M$ framework.

The KBP and KER were challenged by the monetary approach to the balance of payments and exchange rates, MBP and MER, respectively, wherein the money market disequilibrium determines the magnitude of the $B P$, or movements in the exchange rate. Such models generate conclusions with regard to the balance of payments effects of higher domestic output, prices, and interest rates that are the opposite of those suggested by the Keynesian models. More recently, the asset market approach to the determination of exchange rates has replaced the monetary approach. Here, again, various models reach conclusions with regard to the effects of monetary or fiscal policy that differ from the conclusions reached via other models. ${ }^{2}$

As a consequence of the apparent confusion in the literature, Chen [1975], Deardorff [1977], Kierskowski [1979], Miller [1981] and [1986], Frenkel, Gylfason and Helliwell [1980], Allen and Kenen [1980], Gylfason and Helliwell [1982], Ahtiala [1984], and Niehans [1984] have attempted to synthesize the various models. Most of these research efforts are superior to this work in that they contain behavioral equations which are used to solve for conclusions, a methodology that is not used here. However, one is never sure to what extent the conclusions depend on the specification of the model's behavioral equations.

\section{3.}

The conclusions reached here are based upon identities, and, hence, are independent of the specification of the behavioral equations. Other advantages of this approach are that it: (a) provides micro oriented intuitive explanations as to why a balance of payments may be non-zero; (b) obtains new conclusions and/or insights into the working of an open economy; (c) suggests not only that many previous models represent special cases (as is now well

\footnotetext{
${ }^{1}$ See Fleming [1962] and Mundell [1968].

${ }^{2}$ The IMF [1984] study contains an excellent review of many issues on this topic.
} 
known) but that other special case models have yet to be developed; and (d) it investigates which special case models are appropriate for different circumstances.

\section{4 .}

The contribution here represents a general approach or framework for analysis, as in Johnson [1968], but it falls short of a general theory of the balance of payments and exchange rates. The reasons for this will become apparent as we proceed. Section 2 develops the Walrasian identities that lie at the heart of the analysis. This is done both at the micro and macro levels in order to check on logical consistency, and to provide more intuitive insights. Sections 3 and 4 work through each of the special case models of the balance of payments. The implications of our framework are developed in Section 5. Section 6 investigates models of the exchange rate. All conclusions are summarized in Section 7.

\section{The Basic Ideas}

\section{1.}

Most of the literature dealing with the balance of payments utilizes effective supply and demand concepts within a period analysis framework. Consequently, that is the approach used here initially. Any differences that arise within a Walrasian notional demand and supply framework are pointed out in footnotes. A stock-flow version of the effective supply and demand framework is developed near the end of this section and is used in the analysis of exchange rates in Section 6.

We begin by reviewing the macro approach developed in Miller [1981] and [1986], and then moving to an intuitive explanation at the micro-level of what determines individual budget imbalances. The micro and macro approaches are shown to be consistent by summing the budget constraints for all agents within the economy in order to obtain the same Walrasian identities that appear in the macro approach. In all cases, the objective is to obtain Hahn identities (which are defined immediately below) that relate the ex ante balance of payments to the excess demands or supplies within the economy. Finally, this section shows that a similar Hahn identity can be obtained within a stock-flow framework.

\section{2.}

Miller [1981] and [1986] has shown in a four good (tradables $T$, nontradables $N$, bonds $A$, and money, $m$ ) model, that the sum of the period analysis effective demand and supply budget constraints for the household, business, and government sectors of an economy 
lead to the aggregate budget constraint. ${ }^{3}$

$$
E_{T}+E_{N}+E_{A}+E_{m} \equiv 0,
$$

where each $E_{i}$ represents the ex ante domestic supply minus demand for that good. Each $E_{i}$ will be referred to as the "domestic excess supply of good $i$ ". Within a closed economy each $E_{i}$ would be the total market excess supply, but in an open economy it is necessary to take account of international transactions in order to obtain the total ex ante market excess supply for each good, call this $X_{i}$.

By the definition of nontraded goods, it follows that $X_{N}$ equals $E_{N}$. By assumption here, home residents hold only home money, and no home money is held abroad. This represents an important simplifying assumption whose effect on the conclusions has not been explored. Thus, $X_{m} \equiv E_{m}$. The $E_{T}$ term represents the output minus total domestic demand (or absorption) of tradables. Hence, it follows that $X_{T} \equiv E_{T}-B T$, where $X_{T}$ is the total market excess supply of home tradables and $B T$ is the ex ante balance of trade. A similar definition applies to the market excess supply of bonds, i.e., $X_{A} \equiv E_{A}-K F$, where $K F$ represents the ex ante net international capital flow. ${ }^{4}$ With (1) and these definitions, Miller [1986] obtains the identity: ${ }^{5}$

$$
X_{T}+X_{N}+X_{A}+X_{m} \equiv-B P,
$$

where $B P \equiv B T+K F \equiv$ the ex ante balance of payments.

Alternatively, Appendix $A$ shows that (2a) can be obtained directly by summing the budget constraints of: (a) the private sector; (b) the government sector (Treasury plus Central Bank); and (c) the Exchange Stabilization Fund, ESF. The ESF's activities must be taken into account in any model with fixed or managed floating exchange rates. Thus, (2a) is a type of Walrasian identity in that it is obtained by summing all budget constraints. Since it represents an extension of Hahn's [1977] two good identity $X_{T}+X_{m}=-B T$, (2a) will be referred to as Hahn's identity. ${ }^{6}$

Identity (2a) has some intuitive appeal if we define the ex ante balance of payments as the excess supply of foreign exchange $X_{F X}$. Then (2a) can be written as:

${ }^{3}$ This is proven in Appendix A. All identities assume that commodity prices are fixed at unity so that all magnitudes may be considered equivalently as nominal or real. With a notional demand and supply framework, (1) would also contain the excess supply of labor, ${ }^{*} E_{L}$, and would be ${ }^{*} E_{L}+{ }^{*} E_{T}+{ }^{*} E_{N}+$ ${ }^{*} E_{A}+{ }^{*} E_{m} \equiv 0$.

${ }^{4}$ Again, see Appendix A.

${ }^{5}$ The notional version of (2a) is: ${ }^{*} X_{L}+{ }^{*} X_{T}+{ }^{*} X_{N}+{ }^{*} X_{A}+{ }^{*} X_{m} \equiv-{ }^{*} B P$, where ${ }^{*} X_{L}$ is the market notional excess supply of labor, and ${ }^{*} B P$ is the ex ante notional balance of payments.

${ }^{6} \mathrm{Hahn}$ correctly writes this identity in his two good framework, but he incorrectly writes $X_{T}+X_{A}+$ $X_{m} \equiv-B T$ when the excess supply of bonds, $X_{A}$, is added. That is, the right hand side should be $-B P$ instead of $-B T$. 


$$
X_{T}+X_{N}+X_{A}+X_{m}+X_{F X} \equiv 0 .
$$

The sum of the excess supplies in all markets is always zero, just as one would expect. Miller [1981] and [1986] as well as Hahn [1977] use (2a) to point out that a money market disequilibrium will determine the balance of payments only when all other markets are in equilibrium. Miller also points out the obvious inference from (2a), that a disequilibrium in any market may be associated with a payments imbalance. ${ }^{7}$ However, neither he nor Hahn provide the micro-foundations and/or any intuitive explanation for these important conclusions. Moreover, the implications (if any) of (2a) with regard to the balance of payments literature have not been explored.

\section{3.}

Before moving on, it is important to clear up some possible ambiguities. First, the ex ante supplies in (2a) are necessarily of the Keynesian effective demand and supply variety, as defined in Clower [1965], because (2a) and (2b) omit the labor market. That is, the demand terms embedded in the $X_{i}$ implicitly contain income, rather than the real wage rate as one of the independent variables. This framework is used here because most of the literature (even many MBP and MER models) utilizes Keynesian effective demand concepts.

Second, the first fact implies that (2a) and (2b) are not identities of the type first obtained by Walras, wherein the excess supplies are notional in nature. They represent Walrasian identities in the sense pointed out by Muellbauer and Portes [1978], i.e., when any model has a quantity constraint imposed on it by the model builder, then the constrained market drops out of the new relevant Walrasian identity. Thus, since Keynesian effective demand and supply models constrain the labor market, they also have a Walrasian identity, but it omits the labor market excess supply. To avoid confusion, (2a) and (2b) are called Hahn identities.

Third, the analysis in this paper does not attempt to correctly model an open economy under conditions of market disequilibrium. Such an undertaking would involve an investigation of the spillover effects associated with a disequilibrium in any one market, as in Grossman [1971] or Neary [1980]. The objective here is simply to point out that the existing literature has (usually implicitly) assumed that one or more domestic markets are out of equilibrium when the balance of payments is non-zero. The many apparently contradictory conclusions in the literature arise, in part, because different models implicitly assume that different markets are out of equilibrium.

${ }^{7}$ Kuska [1983] calls (2a) “Miller's Theorem," but Hahn must be given credit for first recognizing its existence. 


\section{4.}

Begin at the micro level by considering the circumstances under which an individual economic unit has a budget imbalance, where this term is defined here to imply a net flow of money into (a budget surplus) or out of (a budget deficit) that unit. One obvious cause of individual budget imbalances is that the economic unit is initially unhappy with its money balances. An initial ex ante excess supply (demand) of money will prompt the unit to plan its nonmonetary purchases to exceed (be less than) its nonmonetary sales, so that the appropriate quantity of money will flow out (in).

Such circumstances are similar to what is implicitly assumed in the monetary approach to the balance of payments or exchange rate. Note well that each economic unit may end up with an optimum quantity of money at the end of the time period. This is referred to here by saying that the economic unit's money supply and demand are in balance ex post, even though they were not in balance ex ante. ${ }^{8}$

These ideas can be represented algebraically by assuming " $m$ " different goods, with money being the " $m$-th" good. Each economic unit has an ex ante budget constraint of the form:

$$
\sum_{1}^{m-1} e_{i}+e_{m} \equiv 0
$$

where each $e_{i}$ is defined as an ex ante excess supply. Identity (3a) illustrates the idea that planned net nonmonetary purchases or sales, $\Sigma e_{i}$, must always be nonzero by the same magnitude but opposite sign from any ex ante excess supply or demand for money, $e_{m}$.

In addition, each economic unit faces an ex post budget constraint, that is a weak version of the well known Clower financing constraint. ${ }^{9}$

$$
\sum_{1}^{m-1} \bar{e}_{i} \equiv \Delta m
$$

where each $e_{i}$ equals the ex post sales minus pruchases of good $i$, and $\Delta m>0$ (or $\Delta m<0$ ) represents a net inflow (or outflow) of money. Subtracting (3b) from (3a) yields:

$$
\sum_{1}^{m-1}\left[e_{i}-\bar{e}_{i}\right]+e_{m} \equiv-\Delta m \text {. }
$$

\footnotetext{
${ }^{8}$ Alternatively, we could use the terms "beginning of period disequilibrium" and "end of period equilibrium."

${ }^{9}$ Identity (3b) represents a weak version of Clower's [1967] financing constraint, because it requires a flow of money only for net transactions, and not for gross transactions.
} 
The three identities, $3 \mathrm{a}, 3 \mathrm{~b}$ and $3 \mathrm{c}$ (only two of which are independent) can reproduce the logic of the previous paragraphs with regard to budget imbalances that arise because of an initial level of money balances that is not optimal. For example, an initial ex ante excess supply of money, $e_{m}>0$, will create an ex post outflow of money in (3c), if the ex ante excess demands for nonmonetary goods (which must exist via 3a) lead to actual purchases and sales that equal what are planned, so that each $\left[e_{i}-\bar{e}_{i}\right]$ term in $3 \mathrm{c}$ is zero.

These identities clearly lead to other possible reasons for individual budget imbalances. For example, a unit may be initially happy with its money balances, $e_{m}=0$, but it may be unable to sell all the nonmonetary goods that it plans. As examples, firms may have an unintended build up of inventories, or a government may be unable to find an underwriter for its latest issue of bonds. In such a situation, the economic unit will be forced to draw down its money balances below their previously optimal level.

In terms of (3c), this situation implies that one or more of the ex ante $e_{i}$ terms exceeds the corresponding ex post $\bar{e}_{i}$ term, so that the left side of (3c) is positive, even though $e_{m}=0$. Thus, the $\Delta m$ term in (3c) is negative in a magnitude equal to the net excess of planned sales over actual sales. In such a situation, the unit's money balances are optimal ex ante, $e_{m}=0$, but are not optimal ex post, $e_{m}+\Delta m<0.10$

From Grossman [1971] and others, we know that the inability to sell all that is planned will, in general, exert spillover effects on all other demands and supplies. That is, the agent is likely to decrease the demands for all goods. Our analysis assumes for simplicity that the spillover effects go entirely to the money demand function. When actual sales of some good fall short of planned sales, then people draw down their money balances by this amount. We will see later that this simplifying assumption about spillover effects is implicit in much of the balance of payments literature.

The final possible reason for a budget imbalance is that an economic unit may be unable to buy as much of some goods as it plans. As examples, households may be unable to find the style or brand of certain products, firms may face shortages of labor or raw materials, and governments may be unable to buy some desired types of military goods. In all cases, the economic unit ends up with a budget surplus, provided that $e_{m}=0$ initially, i.e., initial money balances are optimal.

In terms of (3c), if $e_{m}=0$, but one or more of the ex ante $e_{i}$ terms is smaller than the corresponding $\bar{e}_{i}$ term, then the left side of (3c) becomes negative. This creates a net inflow

${ }^{10}$ When working at the micro level, the distinction between the ex ante and ex post excess supply of money is identical to the difference between "beginning of period" versus "end of period" definitions of the excess supply of money as emphasized by Foley [1975] and Buiter \& Eaton [1981]. However, Section 3.1. points out that the meanings of these two sets of terms differ at the aggregate level. 
of money, $\Delta m>0$, that is equal in magnitude to the budget surplus. Notice, again, that there is an ex ante equality of money supply and demand, but a positive ex post excess supply of money for this economic unit, $e_{m}+\Delta m>0$.

It is explained below that these last two reasons for budget imbalances (i.e., nonmonetary excess supplies or demands) are related: (a) to the Keynesian approach to the balance of payments, and (b) to new theories of the balance of payments that have yet to be developed.

\section{5.}

In order to go from (3c) to the Hahn identity (2a), it is necessary to sum (3c) over all economic units (assuming that there are " $n$ " of them) and to assume that only four goods exist. For notational simplicity, let $E_{i}$ represent the sum of the ex ante $e_{i}$ over all "n" economic units; and $\bar{E}$ the sum of the ex post magnitudes. Summing (3c) then gives:

$$
\left(E_{T}-\bar{E}_{T}\right)+\left(E_{N}-\bar{E}_{N}\right)+\left(E_{A}-\bar{E}_{A}\right)+E_{m} \equiv-\sum_{1}^{n} \Delta m_{j},
$$

where the net flow of money is summed over all economic units, $j=1 \ldots n$.

The right side of (4a) equals minus the ex post balance of payments for this economy. In order to obtain (2a) from (4a), it is necessary to assume that all planned international transactions are always carried out, so that the ex post balance of payments is also the ex ante balance of payments. More formally, we assume that spillover effects from market disequilibria do not alter the ex ante balance of payments, the latter being determined by the home primary demands for imports and foreign bonds and primary foreign demands for home exports and home bonds.

In (4a), each $\bar{E}_{i}$ term represents the net ex post sales minus purchases of good $i$ by home residents. Thus, $\bar{E}_{N}$ is always zero by the definition of nontraded goods. Moreover, $\bar{E}_{T}$ is the ex post balance of trade, which, by the assumption of the previous paragraph also equals the ex ante balance of trade. ${ }^{11}$ Similar reasoning leads to the fact that $\bar{E}_{A}$ equals the ex post and ex ante net international capital flow. In sum, (4a) can be rewritten as:

$$
\left(E_{T}-B T\right)+E_{N}+\left(E_{A}-K F\right)+E_{m} \equiv-B P .
$$

From the definitions of the market excess supplies, $X_{i}$, given earlier, identity (4b) corresponds to identity (2a).

This, then, provides the intuitive explanation for the conclusions suggested by (2a) and ( $2 \mathrm{~b}$ ). A balance of payments deficit (surplus) occurs when one or more markets are in

${ }^{11}$ The ex ante balance of trade is demand determined here (e.g., export and import demands), as in most open economy models. 
a state of excess supply (demand). When the money market is out of equilibrium, then the logic is exactly as presented by the $M B P$. However, when a nonmonetary market is out of equilibrium, then the country experiences a $B P$ deficit (surplus) when home residents cannot sell (buy) all that they plan. For example, a payments deficit may be associated with the inability to sell as many traded goods as planned. Thus, home residents draw down their money balances and in the aggregate this requires a balance of payments deficit.

A payments surplus implies that home agents are unable to purchase all the goods that they plan. Hence, money balances build up, and in the aggregate this requires a $B P$ surplus. We will see in Section 3 that the $I S, L M$, and $B P$ curve approach to the balance of payments (i.e., the $K B P$ ) implicitly assumes that the home bond market is out of equilibrium. Moreover, no one has yet developed a theory of payments imbalances associated with disequilibrium in the traded or nontraded goods markets.

\section{6.}

The discussion and algebra so far refer only to discrete time or period analysis models. Within a continuous time or stock-flow model, each economic unit (or sector) faces two budget constraints, a flow constraint and a stock constraint. Appendix $B$ shows that in a four good model, this leads to two aggregate budget constraints for the economy.

$$
\begin{gathered}
F E_{T}+F E_{N}+F E_{A}+F E_{m} \equiv 0 \\
E_{A}+E_{m} \equiv 0 .
\end{gathered}
$$

The $F E_{i}$ terms are the home ex ante flow excess supplies for each good; the $E_{i}$ are the home ex ante stock excess supplies. As in the discrete time framework, these terms do not represent total market excess supplies in an open economy. Appendix B shows that when (5a) and (5b) are altered to take account of international transactions, we obtain the Hahn identities.

$$
\begin{gathered}
F X_{T}+F X_{N}+F X_{A}+F X_{m} \equiv-B T-K F_{f} \\
\phi X_{A}+\phi X_{m} \equiv-K F_{s}
\end{gathered}
$$

Identity (6a) tells us that the sum of the market ex ante flow excess supplies, $F X_{i}$, equals minus the balance of trade and minus the net flow-adjustment component of international capital flows, $K F_{f}$. Identity (6b) shows that the sum of the stock excess supplies equals minus the net stock adjustment component of international capital flows, $K F_{s} .12$ [The $\phi$ term is explained momentarily].

\footnotetext{
${ }^{12}$ Miller \& Whitman [1970] define $K F_{f}$ and $K F_{s}$.
} 
By definition, we cannot add stock and flow terms, but in reality we always add the current account or balance of trade magnitude to the total net international capital flow, $K F_{f}+K F_{s}$, in order to obtain the balance of payments magnitude. Thus, it is useful to follow Foley [1975] by converting the stock excess supply terms, the $X_{i}$ in $6 \mathrm{~b}$, to flow terms by multiplying each of them by a positive speed of adjustment variable, $\phi \leq 1$. Since the units of $\phi$ are (1/time period), it follows that each $\phi X_{i}$ in (6b) is a flow term. ${ }^{13}$

Thus, we can add (6a) and ( $6 \mathrm{~b})$ to obtain:

$$
F X_{T}+F X_{N}+\left[F X_{A}+\phi X_{A}\right]+\left[F X_{m}+\phi X_{m}\right] \equiv-B T-K F_{f}-K F_{s} .
$$

This illustrates the ideas that: (a) the balance of payments includes the $B T$ and stock adjustment, $K F_{s}$, and flow adjustment, $K F_{f}$, components of international capital flows; (b) the underlying causes of a nonzero balance of payments include pure flow disequilibria (the $F X_{i} \neq 0$ ) as well as stcck disequilibria (the $X_{i} \neq 0$ ); $;^{14}$ and (c) the bond and money markets can conceivably te in equilibrium even though neither term within the square brackets $\left[F X_{i}+\phi X_{i}\right]$ is zero. Identity (7) will prove especially useful in Section 6 when we examine modern theories of the exchange rate.

\section{The Monetary Approach to the Balance of Payments}

\section{1.}

Even though several authors have correctly shown that the monetary approach to the balance of payments, $M B P$, represents a special case, there still appears to be some confusion on this subject. This section explains that the confusion exists because: (a) alternative definitions of the excess supply of money are used $;^{15}$ (b) the $M B P$ appears in a single equation as well as a macro-model form; moreover, the macro-models include both the extreme small country versions (wherein the home country cannot alter prices or interest rates at home or abroad) and the semi-small country versions (wherein the home country cannot affect foreign variables, but it can alter the prices of its own commodities and assets); and (c) the most well known and controversial conclusions of the $M B P$ hold only under very restrictive assumptions, i.e., they do not always hold even in models wherein the

\footnotetext{
${ }^{13}$ Of course, $\phi$ can be unity without altering any conclusions.

${ }^{14}$ This is consistent with the Harry Johnson [1968] insight that a payments imbalance may be (a) of an inherently temporary stock-adjustment nature; or (b) of a more permanent flow adjustment nature.

${ }^{15}$ See Kuska [1978] and [1982], Deardorff [1981], Buiter \& Eaton [1981] and Miller [1981]. Another source of confusion that came out of this exchange is that some authors define the ex ante trade balance and capital flow in terms of what home residents plan, while others define the ex ante $B T$ and $K F$ as being demand determined.
} 
ex ante balance of payments is constrained by assumption to equal the ex ante disequilibrium in the money market.

Some authors define the excess supply of money in the manner implied by our identities above; that is, $X_{m}$ excludes the current period's flow of international reserves. This assumption is implicit in the standard $I S, L M$, and $B P$ curve models, wherein a non-zero balance of payments alters the money supply and shifts the $L M$ curve in the next time period. Such a definition of $X_{m}$ has also been used by $M B P$ advocates such as Kuska [1978]. It is what Massaourakis [1983] and our definitions have called the ex ante excess supply of money.

Alternatively, many models utilize an ex post definition of the excess supp'y of money, call this $\bar{X}_{n}$, wherein the current period's flow of international reserves is included as part of the money supply. In more precise terms,

$$
\begin{aligned}
\text { Ex Ante Definition: } & \text { (8a) } X_{m} \equiv D_{0}+R_{0}+\Delta D-L \\
\text { Ex Post Definition: } & \text { (8b) } \bar{X}_{m} \equiv D_{0}+R_{0}+\Delta D+\Delta R-L \\
\text { or } & \text { (8c) } \bar{X}_{m} \equiv D+R-L
\end{aligned}
$$

where $D$ is the domestic asset component of base money, $R$ is international reserves, $L$ is money demand, an the price level and money expansion multipliers are set equal to unity. Notice that the ex post version (8c) defines $D$ and $R$ to be inclusive of current changes in these variables.

Buiter and Eaton [1981] and others maintain that if "end of period" definitions of asset supplies are used, then the current period's flow of international reserves $\Delta R$, must be counted as part of the money supply; if so, then, allegedly, (8b) and (8c) are the correct definitions.

In other words, according to this point of view, money market equilibrium should be specified as $\bar{X}_{m}=0$ rather than $X_{m}=0$. When this is done, however, then the model builder is constraining the balance of payments, $\Delta R$, to always equal minus the ex ante excess supply of money, $X_{m}$, i.e., $\bar{X}_{m}=0$ is synonymous with $X_{m}=-B P$ if $B P \equiv \Delta R$. Consequently, a payments imbalance can never be associated with a disequilibrium in a nonmonetary market. Since we know from our micro analysis that budget imbalances can arise for reasons other than a monetary disequilibrium, it follows that payments imbalances can conceivably be caused by disequilibria in nonmonetary markets. Since (8b) and (8c) preclude this, they cannot be the only way to define money market equilibrium.

The obvious question, then, is: "how can we justify the use of (8a) in a model that uses 'end of period' asset supplies?" The answer involves a distinction between ex ante and ex post end of period supplies. For example, it is well known that a home country ex ante payments deficit, implies that an ex ante excess demand for foreign exchange, or a negative 
excess supply, $X_{F X}<0$, exists. We know that the latter cannot occur (i.e., it would quickly be eliminated via an exchange rate variation) unless the exchange stabilization fund, E.S.F., sells international reserves, $\Delta R<0$, to satisfy the excess demand for foreign exchange. If we include the E.S.F.'s activities, then the foreign exchange market is in balance. However, clearly $\Delta R$ is not part of the ex ante supply of foreign exchange; it is part of the ex post supply of foreign exchange. Thus, the foreign exchange market remains out of equilibrium in an ex ante sense.

The same logic applies to the money market. Definition (8a) includes the "end of period" magnitude, $D+\Delta D$, for the domestic asset component of base money, but it excludes the current $\Delta R$ via the logic of the previous paragraph. If $\Delta R$ is not part of the ex ante end of period supply of foreign exchange, then it is reasonable to assume that $\Delta R$ is also not part of the ex ante end of period supply of money. ${ }^{16}$

The second source of confusion on the subject of the $M B P$ concerns the fact that the original version by Harry Johnson [1972] as well as many empirical $M B P$ papers use a single equation model such as (8b) or (8c). However, others, as for example, Dornbusch [1980] Ch. 7., and the synthesis models of Frenkel, Gylfason, and Helliwell [1980] as well as Niehans [1984] include equations such as (8b), (8c) or their equivalent, $X_{\dot{m}}=-B P$, within a macro-model. That is, the ex ante balance of payments is assumed to equal the disequilibrium in the money market, and the model contains equilibrium equations for other markets. In other words, these synthesis models are really just macro-model (rather than single equation) versions of the $M B P$.

Hence, there are both single equation and macro-model versions of the $M B P$. However, as well shall see shortly, the marco-model versions do not reach the same conclusions as the single equation versions when they do not make the special small country assumptions that are implicit in the single equation version. These special assumptions or lack of them are the third source of confusion.

\section{2.}

Both (2a) and (4b) tell us that the ex ante balance of payments equals minus the ex ante excess supply of money only when all other markets are in equilibrium. In the case of a small country that can sell or buy any amounts of tradables or bonds at the world's price and interest rate, the $X_{T}$ and $X_{A}$ terms are always zero by assumption. If non-traded goods are assumed not to exist, the both (2a) and (4b) reduce to $X_{m}=-B P$, or, equivalently, they yield $(8 b)$ or $(8 c)$. Thus, the small country assumption is implicit in the single equation

\footnotetext{
${ }^{16}$ Models that include (8b) or (8c) do not contain a logical error; they may be interpreted as specifying. $X_{m} \equiv-\Delta R$, which is quite sound.
} 
versions of the $M B P$. In the macro-model versions of the $M B P$, the model contains equilbrium equations such as $X_{T}=0$, and $X_{N}=0$, in addition to either (8b), (8c) or their equivalent, $X_{m}=-B P$.

The crucial difference between the single equation or small country macro-model versions of the $M B P$ and the semi-small country macro-model versions of the $M B P$ is that: (a) in the former all nonmonetary markets clear instantaneously via automatic changes in the balance of trade (to equal $E_{T}$ in $4 \mathrm{~b}$ ); and automatic changes in net capital flows (to equal $E_{A}$ in $4 \mathrm{~b}$ ); (b) but in the $M B P$ semi-small country macro-models, the tradable goods and bond markets clear only via changes in endogenous viarables such as income, prices or interest rates. It is these changes in endogenous variables that lead to different conclusions in the semi-small country macro-model versions of the $M B P$, because such changes feed back to the excess supply of money. In order to see this, it is best to work through several examples. The examples will also highlight the difference between what Rabin and Yeager [1979] and [1983] call the strong $M B P$ and the weak $M B P$.

\section{3.}

Assume that all markets are intially in equilbrium, and that the balance of payments is zero; then let a monetary shock create an ex ante excess supply of money. Such a shock could be an increase in the nominal money supply or an exogenous decrease in the demand for money. This excess supply of money implies that $E_{m}$, the domestic excess supply of money, is positive in (1) and (4b) and that $X_{m}$ (which equals $E_{m}$ by definition) is positive in (2a).

Does this, in itself, imply that the $B P$ in (2a) or (4b) is negative? The answer is, no! The economy's aggregate budget constraint, (1), ensures that no $E_{i}$ term can change in isolation. There will be one or more of the nonmonetary $E_{i}$ terms in both (1) and (4b) that are negative by magnitudes that just cancel the positive $E_{m}$. If people demand less money, then they must demand more of other goods; when the government supplies more money, then it must demand more bonds or commodities. Hence, the $B P$ term on the right side of ( $4 b)$ and (2a) initially remains zero when a shock creates an excess supply of money.

In the single equation and small country macro-model versions of the $M B P$, the payments deficit arises because the trade balance and/or net capital flow automatically become negative to clear the traded goods and bond markets. To explain, from (1), it follows that in the absence of nontraded goods, a positive $E_{m}$ must be matched by negative values for the domestic excess supply of tradables, $E_{T}$, and/or of bonds, $E_{A}$; that is, a domestic excess supply of money implies either a domestic excess demand for tradables or a domestic. excess demand for bonds, or both. 
In the single equation $M B P$ or small country macro-model version, the balance of trade, $B T$, instantaneously becomes negative in an amount equal to the negative $E_{T}$ in (4a) so that the home tradable goods market always clears, i.e., $X_{T} \equiv E_{T}-B T \equiv 0$. Similarly, the net capital flow, $K F$, instantaneously becomes negative to equal the negative home excess supply of bonds, $E_{A}$; thus, $X_{A} \equiv E_{A}-K F \equiv 0$.

Since the sum of $E_{T}+E_{A}$ initially equals minus the domestic excess supply of money, $E_{M}$, and since the sum of $B T$ and $K F$ adjusts to equal $E_{T}+E_{A}$, it follows that the balance of payments is in deficit by the amount of the excess supply of money. The offset coefficient $d R / d D$ is minus unity, -1 . All of this, of course, requires that nontraded goods do not exist. If they do, then from ( $2 a$ ) any disequilibrium in this market will destroy the one to one relationship between $X_{m}$ and $-B P$, even in small country models. As Rabin [1979] has shown, the single equation $M B P$ is, in general, invalid in the presence of nontraded goods.

In the semi-small country macro-model versions of the $M B P$, the scenerio begins in the same manner. When $E_{m}$ and $X_{m}$ become positive via a monetary shock, then there is no initial impact on the balance of payments, because (in the absence of nontraded goods) (1) requires that $E_{T}$ and/or $E_{A}$ become negative, and, from (4b), the $B P$ remains zero. In terms of (2a), the positive $X_{m}$ is matched by negative values for $X_{T}$ and/or $X_{A}$. (Again, we are ignoring the presence of nontraded goods.) Then the endogenous variables in the model adjust to return $X_{T}$ and $X_{A}$ to zero. If the model builder has constrained the balance of payments to equal the ex ante excess supply of money via an equation such as (8b) or (8c), then this ensures that the endogenous variables will continue to adjust until $X_{T}=0=$ $X_{A}$, and $X_{m}=-B P$.

However, the higher output and/or higher prices that are needed to eliminate the initial excess demand for tradables will reduce the initial excess supply of money. The lower interest rate that is required to eliminate the initial excess demand for bonds will also reduce the excess supply of money. Consequently, in the semi-small country macro-model versions of the $M B P$, the $B P$ deficit equals the excess supply of money, but the final excess supply is less than the initial excess supply. In other words, the offset coefficient is less than unity in absolute value.

\section{4.}

In the case of a monetary shock, all versions of the $M B P$ generate the conclusion that an initial excess supply of money leads eventually to a payments deficit. Rabin and Yeager [1979] and [1983] call this the strong version of the $M B P$. But what if the initial shock to the economy occurs elsewhere, say via an increase in the foreign demand for home exports or in 
the foreign demand for home bonds? In such a case, none of the $E_{i}$ terms in (1) or (4b) change initially, because the $E_{i}$ include only home supplies and demands. The $B T$ and $K F$ terms appear in $X_{T}$ and $X_{A}$ in (2a) or (4b) with a minus sign, so that an improvement in the $B T$ or $K F$ creates an excess demand for home tradables or bonds, respectively. Thus, the $X_{T}$ and $X_{A}$ terms in (2a) become negative. In (2a), the negative values for $X_{T}$ and/or $X_{A}$ are matched by a positive $B P$ on the right side.

In such a situation, the balance of payments is nonzero, even though the money market is initially in a state of ex ante equilibrium; i.e., by assumption, the shock does not have an impact on $E_{m}$ or $X_{m}$. In the small country $M B P$, such an exogenous shock to exports or net capital flows is impossible, because of the assumption that the rest of the automatically supplies or demands whatever home residents desire, i.e., $B T$ and $K F$ are endogenous variables. ${ }^{17}$

In the semi-small country macro-model versions of the $M B P$, these foreign shocks that create an excess demand for home tradables and/or home bonds will cause equilibrating movements in home output and/or prices and home interest rates. The increases in home output and prices serve to bring $X_{T}$ back to zero, but they help to increase the demand for money. Similarly, the lower interest rate (that is needed to eliminate the initial excess demand for home bonds) also increases home money demand. If the model builder has constrained the $B P$ or $\triangle R$ to equal minus $X_{m}$, then eventually the endogenous variables will move enough to accomplish this, and to clear all other markets.

Thus, the payments surplus equals the ex ante excess demand for money, but now the direction of causation has been reversed. The initial shock to the balance of payments initially does not disturb the money market. However, the ensuing events eventually create an ex ante excess demand for money that matches the inflow of reserves and leads to money market equilibrium in an ex post sense. In such a case, the $M B P$ is not a theory as to what causes a payments imbalance. (Recall that the positive $B P$ is initially associated with excess supplies of tradables and bonds.) Rather, the $M B P$ is now simply a framework for investigating what must happen in order for people to willingly hold the money that flows in via the payments surplus. Rabin and Yeager [1979] and [1983] call this the weak $M B P$.

Section 3.3. investigated how a monetary shock creates an ex ante excess supply of money that leads eventually, to a payments deficit. Here in Section 3.4. we have explored the reverse case wherein a $B P$ shock eventually creates an ex ante excess demand for money. There remains the possibility of: (a) shocks that initially affect neither $X_{m}$ nor the

${ }^{17}$ Ahtiala [1984] has correctly pointed out that the small country macro-model versions of the $M B P$ contain $B T$ and $K F$ as the endogenous variables that move to clear the home markets for traded goods and bonds. 
$B P$, but ensuing events change both $X_{m}$ and $B P$ in a manner that is consistent with the $M B P$; or (b) a nonmonetary shock initially alters both $X_{m}$ and $B P$, as well as, perhaps, other markets. An analysis of these cases of the weak $M B P$ is left as an exercise for the reader.

\subsection{A Perspective}

It is important to understand what is not implied by our analysis. The basis idea in this paper is that a payments imbalance must always be associated with one or more nonzero terms on the left side of (2a) or (4b), and that this implies an initial disequilibrium in one or more markets. None of this precludes the possibility that all markets can be in equilibrium at the end of our period analysis time interval.

To explain, it is possible for a shock to send one or more markets out of equilibrium, and for these markets to adjust slowly enough that they remain out of equilibrium at the end of the first time period. In such a case, the magnitude of the balance of payments is determined by minus the sum of all market excess supplies. However, the discussion immediately above makes it clear that in the semi-small country macro-model versions of the $M B P$, any initial disequilibrium in a nonmonetary market is completely eliminated at the end of the time interval. In terms of (2a), any initially nonzero nonmonetary $X_{i}$ will create or be associated with a payments imbalance even though the money market is initially in equilibrium, i.e., $X_{m}=0$. Then, by assumption in these models, the endogenous variables adjust until all nonmonetary $X_{i}$ are zero and the magnitude of $X_{m}$ is nonzero by exactly the amount of the payments imbalance, i.e., people willingly accept or give up the money associated with the nonzero $B P$. Thus, the ex post excess supply of money, $\bar{X}_{m} \equiv X_{m}+$ $\Delta R$, is zero, and all markets are in equilibrium at the end of the time interval.

The point is that commodity and other nonmonetary market shocks and disequilibria can be the true "cause" of payments imbalances, but it is possible to model an economy in a manner that (a) leads to full equilibrium at the end of the time period; and (b) makes it look as though the only cause of payments imbalances is a money market disequilibrium. Such modeling obscures, but does not in any way negate, the fact that the micro-foundation of payments imbalances includes more than money market disequilibria.

\section{Keynesian and Other Approaches to the Balance of Payments}

\section{1.}

Section 1.2. pointed out that the Keynesian approach to the balance of payments, $K B P$, refers to the traditional Mundell-Fleming, $I S, L M$, and $B P$ curve models that appear in 
many textbooks. ${ }^{18}$ In these models, $X_{m}$ is (by assumption) not affected by the current period's balance of payments. This may occur simply by the manner in which $X_{m}$ is defined, or it may occur by invoking the assumption of complete short run sterilization by the monetary authorities.

The $K B P$ models usually ignore nontraded goods and include the three equations:

$$
\begin{gathered}
X_{T}=0 \\
X_{m}=0 \\
B P=B T()+K F(),
\end{gathered}
$$

where the $B T(\quad)$ and $K F()$ terms represent behavioral functions for the balance of trade and net capital flows, with the latter often omitted from the model. The short run versions of these models do not constrain the balance of payments to equal zero. In such a case, it is apparent from (9a)-(9c) and from (2a) that these $K B P$ models imply that any nonzero balance of payments equals the disequilibrium in the home bond market, i.e., $X_{A}=$ $-B P$.

The intuition is as follows. When home residents cannot sell all the bonds that they plan, i.e., $X_{A}>0$, then they must draw down their money balances. The assumption that all spillover effects fall entirely on the demand for money means that all planned purchases within the economy are actualized by the drawing down of cash balances. This is possible in the aggregate only via a payments deficit, and the negative $B P$ equals the excess supply of bonds. On the other hand, if home agents cannot buy all the bonds that they plan, $X_{A}<$ 0 , then they must add to their money balances, which, in the aggregate, requires a $B P$ surplus.

Modern economies have rather efficient bond markets that appear to react very quickly to exogenous shocks. ${ }^{19}$ Thus, the $K B P$ 's implicit assumption of a disequilibrium in the bond market may not be as appropriate in advanced economies as in the many developing countries that maintain a policy of pegging interest rates below their market clearing values. Such interest rate policies imply that credit markets are in a constant state of excess demand. Within the context of our simple macro-model, this translates to a chronic excess supply of bonds $X_{A}>0$. But since $X_{A}=-B P$ in the Keynesian models, this implies that such developing countries will have chronic balance of payments deficits, as is often observed. Consequently, the $K B P$ models may have special relevance for such

18 Williamson [1983] contains an excellent account of such models.

${ }^{19}$ See, however, Ferguson and Hart [1985] who find empirical evidence of bond market disequilibrium and spillovers to the commodity market. 
economies.

\section{2.}

The simplest version of the income-absorption approach to the balance of payments usually ignores nontraded goods, and implicitly assumes that the money market is constantly in equilibrium via the actions of the monetary authorities, who automatically supply whatever money people want to hold at the target interest rate. Furthermore, such models usually assume that bonds are not traded internationally, so that the balance of trade is the only component of the balance of payments. With these assumptions, identity ( $2 a$ ) becomes:

$$
X_{T}+X_{A} \equiv-B T \text {. }
$$

The main conclusion of the income absorption approach is well known, namely that the trade balance cannot be improved unless output rises relative to the absorption of tradable goods. The general approach to the balance of payments allows us to view this conclusion from a new perspective. We know from (10) that commodity market equilibrium, $X_{T}=0$, implies that the excess supply of bonds equals minus the trade balance. Also, if bonds are not traded internationally, then $X_{A}$ equals $E_{A}$ in (1).

Under such circumstances, Appendix $C$ shows that the home excess supply of bonds, $E_{A}$, equals the absorption of tradables minus the output of tradables. Thus, the policy conclusion about reducing absorption relative to income amounts to increasing bond demand relative to bond supply, and thereby eliminating the excess supply of bonds that is at the heart of the balance of trade deficit.

\section{3.}

Identities (2a) and (4b) suggest that other special case approaches to the balance of payments (in addition to the $M B P$ and $K B P$ ) have yet to be developed. There are two possibilities, both of which relate to commodity market disequilibrium. Algebraically,

$$
X_{T}=-B P,(11 \mathrm{a}) \text { and } X_{N}=-B P(11 \mathrm{~b})
$$

represent the two possibilities, i.e., the balance of payments may be nonzero because of a disequilibrium in either the traded goods or nontraded goods market.

$K B P$ papers often contain statements that appear to relate a payments or trade deficit to an excess demand for commodities. Statements such as, "when demand is too high, then imports become excessive, and the country experiences a balance of trade deficit" are typical. However, Keynesian models always contain a commodity market equilibrium equation, $X_{T}=0$. The hypothetical quotation given here refers only to home output versus 
total home demand, i.e., $E_{T}=y_{T}-A b_{T}$, where $A b_{T}$ represents the domestic absorption of tradables. Obviously, if the commodity market is in equilibrium, then a trade deficit cannot be caused by a total market excess demand for tradables; it is caused by an excess of home demand over home supply of tradables, $E_{T}<0$.

It seems surprising that no one has developed a tradable goods disequilibrium theory of the balance of payments. Intuitively, one might expect that a $B P$ deficit that is tied up with a large excess of imports over exports might be associated with an excess supply of home tradables. In such a case, (11a) represents the relevant balance of payments equation. We will see below that such a possibility has important policy implications with regard to payments deficits. Finally, as noted above, Rabin [1979] discovered that a disequilibrium in the nontraded goods market might create or be associated with a payments imbalance; but apparently no one has attempted to develop this.

\section{The Gen aral Approach Reconsidered}

This section first considers which market or markets are most likely to adjust slowly, and, hence, remain out of equilibrium for at least one time period. Then, we point out the implications of the general approach to the balance of payments with regard to: monetary and fiscal policy in an open economy; exogenous changes in exports or capital flows; the effects of economic growth on the balance of payments; and balance of payments adjustment policies.

\section{1.}

An obvious question that the above analysis suggests is: "if a payments imbalance is always associated with one or more non-clearing markets, then which markets are the culprits?" $M B P$ advocates vote for the money market, but their pursuasive argument loses much of its appeal when placed within a general equilibrium framework. The $M B P$ logic goes something like this.

If people always do only what is optimal for them, and if a payments surplus (deficit) requires a net inflow (outflow) of money, then obviously people must have an initial ex ante excess demand (supply) for money. If not, then why do the home residents accept (give up) the money? Since we observe nonzero values for the $B P$, this implies that money markets must often be out of balance in an ex ante sense, and, hence, this is the underlying cause of payments imbalances. 
The error in this logic is the failure to distinguish between the ex ante excess supply of money at the beginning of the period and at the end of the period. The two can differ for two types of reasons. First, we already know that the macro-model versions of the $M B P$ assume that a shock to any market will eventually change the values of the model's endogenous variables in a direction that creates an ex ante excess supply or demand for money (at the end of the time period) that just equals the payments imbalance, even though the money market was initially in equilibrium after the shock. Second, there may be spillover effects on the demand for money in response to a disequilibrium in some other market. ${ }^{20}$ For example, assume that the primary ex ante excess supply of money is zero at the beginning of the time period, but that people cannot sell all the bonds that they desire. This bond market disequilibrium may prompt people to draw down on money balances and/ or to demand fewer commodities. To the extent that such a situation is associated with a payments deficit, people willingly give up the money, but this willingness is based on a spillover effect. Since the initial primary excess supply of money is zero by assumption, it is incorrect to attribute the nonzero $B P$ to an initial excess supply of money. Both in this case (and in the case where changes in the values of endogenous variables alter $X_{m}$ ) the payments imbalance and the nonzero excess supply of money arise because a nonmonetary market is initially out of equilibrium.

Even though a payments imbalance does not necessarily require the primary excess supply of money to be nonzero, it is still possible that the money market is the one that typically does not clear instantaneously. Indeed, in Milton Friedman's well known closed economy version of the quantity theory, any disequilibrium in the money market is eliminated very slowly via the spillover effects of the nonzero $X_{m}$ on the demand for commodities and on prices. Such a view of the world is perfectly consistent with a modern version of the $M B P$, and, indeed, one might opt for $X_{m}$ being the culprit in a world where the nominal money supply can be fixed exogenously by the government.

However, there is a highly respectable point of view that the money supply is determined endogenously in a world where most of what we call money is in the form of bank deposits. ${ }^{21}$ This perspective suggests that a temporary excess supply of money can be eliminated without waiting for prices to rise (to reduce the real money supply) or for a payments deficit to reduce the nominal money supply. Rather, any temporary excess supply of money is quickly eliminated via the transfer of funds from demand deposits to time deposits or other assets whose short run supply is perfectly elastic.

\footnotetext{
${ }^{20}$ See Grossman [1971] and Ott, Ott and Yoo [1975], Ch. 19 and Muellbauer and Portes [1978] for a discussion of disequilibrium and spillover effects.

${ }^{21}$ See the discussion and references in Cohen [1984].
} 
The $M B P$ is also not relevant in an economy wherein the monetary authorities focus monetary policy on interest rates. In such a case, the money market will always be in equilibrium since the central bank automatically creates whatever money people want to hold at the policy determined interest rate. ${ }^{22}$ In such a situation, the $X_{m}$ term drops out of (2a), and the $B P$ is determined by nonmonetary matters.

As we know, the Keynesian models assume implicitly that the bond market does not clear. As was pointed out above, such an assumption appears to be more relevant for developing countries than for advanced economies with well developed bond markets. However, our simple macro-model lumps together all nonmonetary assets into the asset called "bonds." In reality, there exist thousands of different assets, including capital goods, land, and other property. Realistically, then, $X_{m}$ must represent the excess supply of all nonmonetary assets. It seems possible that the markets for some of these assets might be slow to clear. If so, then such markets are excellent candidates for the culprits or "causes" of payments imbalances.

The final two candidates for nonclearing markets are those of traded and nontraded goods. The literature on sticky prices suggests that prices do not move to clear commodity markets instantaneously. Also, any country that finds itself with excess capacity in the export and import competing industries might be experiencing an excess supply of tradables, and a concommittant payments deficit. A commodity market approach to the balance of payments might be particularly relevant in highly open economies wherein the balance of payments usually moves in the direction of positive or negative export shocks.

\section{2.}

The general approach to the balance of payments analysis provides a new perspective on the balance of payments effects of monetary and fiscal policy within an open economy. As we now know, essentially all of the models in the literature implicitly assume either that the money market or that the bond market does not clear in an ex ante sense. Future work must investigate the direction and relative strengths of monetary and fiscal policy on output and the balance of payments within models that allow for disequilibrium in the traded and nontraded goods markets.

However, the obvious implication of the general approach to the balance of payments is that monetary and/or fiscal shocks will have absolutely no effect on the balance of payments if all domestic markets clear instantaneously. This important conclusion suggests that the model builder pay careful attention to: (a) which market(s) is (are) assumed to be

${ }^{22}$ Kuska [1983] and Ahtiala [1984] correctly point this out. 
initially out of equilibrium, and to (b) the logical consistency of the models.

For example, it is well known that in $K B P$ models, a bond financed fiscal expansion will create a $B P$ surplus (deficit) if the $L M$ curve is steeper (flatter) than the $B P$ curve. Either outcome is conceivable, but many authors assume that $d B P / d G$ is positive. However, we now know that the $K B P$ assumes that the bond market does not clear initially, and that $X_{A}=-B P$. The relevant question then becomes, "how does a bond financed fiscal expansion initially (before bond market equilibirum is attained) affect the bond market?" If any event is likely, then an excess supply of bonds seems likely, at least temporarily. If so, then $\mathrm{d} B P / \mathrm{d} G$ is negative.

\section{3.}

Next, let us explore how exogenous decreases in the foreign demand for home tradables or for home bonds affect the home balance of payments. That is, $B T$ and $K F$ decrease exogenously. If $B P=0$ initially, then within the general equilibrium framework given by (2a), these two events immediately create a payments deficit. A negative $B P$ requires a positive excess supply for one or more home goods in (2a) and (4b). Recall that the total market excess supplies, $X_{i}$, are related to the domestic excess supplies, $E_{i}$, via $X_{T} \equiv E_{T}-B T$ and $X_{A} \equiv E_{A}-K F$. Therefore, if all markets are initially in equilibrium, then an exogenous decrease in $B T$ immediately creates an excess supply of home tradables; similarly an exogenous decrease in $K F$ serves to make $X_{A}$ positive.

In sum, payments deficits (surpluses) that arise from exogenous decreases (increases) in foreign demands for home tradables and/or home bonds (the latter may happen when people speculate in anticipation of an exchange rate variation) initially involve either a commodity market or a bond market disequilibrium. Thus, the bond and the tradable goods markets are the most likely candidates for the nonclearing market in all cases wherein a payments imbalance arises from shifts in foreign demand. This has important implications with regard to the modeling of highly open semi-small economies.

\section{4.}

The empirical discovery of the tendency for net international capital flows to move procyclically ${ }^{23}$ led Harry Johnson [1966] and others to point out that exogenous increases in home output have an ambiguous effect on the balance of payments. Economic growth deteriorates the trade balance if imports respond positively to higher home incomes, but the capital account improves if capital flows move procyclically; there appears to be no a

\footnotetext{
${ }^{23}$ See Branson [1968] and Miller and Whitman [1970].
} 
priori reason why either event should dominate.

In contrast to this, the $M B P$ suggests that an exogenous increase in home income serves to increase the demand for money and create a payments surplus. ${ }^{24}$ These conclusions have a counterpart in the Keynesian, $K E R$, and monetary, $M E R$, theories of the exchange rate. In the $K E R$, growth leads to a depreciation of the home currency, but it appreciates the home currency in the $M E R .^{25}$

Dornbusch [1971] uses the $M B P$ to apparently generate the uncertain results described in previous paragraphs. However, the uncertain effect of growth on the $B P$ in his model dces not arise from the influence of higher income (or growth rates) on the balance of payments. This effect is always positive in the Dornbusch model, because growth increases the demand for money, and the model contains the equivalent of the $M B P$ equation $X_{m}=$ $-B P$. The uncertain effect arises because Dornbusch assumes that growth always increases the government budget deficit. When this is financed in part via a monetary expansion, then the net effect on $X_{m}$ (and hence, on the $B P$ ) from the higher growth rate and the concommitant more rapid monetary expansion is uncertain.

The uncertainty associated with growth and the balance of payments that was pointed bout by Harry Johnson has been generated within a semi-small country $M B P$ macro-model by Frenkel, Gylfason, and Helliwell [1980]. The synthesis model presented in their paper contains an equation similar to (8c); hence, it is an $M B P$ macro-model. In this model, an increase in income tends to increase the demand for money and improve the balance of payments in the true $M B P$ tradition. But growth also lowers the price level, which increases the real money supply and tends to create a payments deficit. The net effect is uncertain.

The general approach to the balance of payments tells us that an exogenous increase in output (via a positive commodity supply shock) will have no effect on the balance of payments if all markets remain in equilibrium. If one market is assumed not to clear, then the conclusion may depend on which market is involved and on how this market responds to exogenous increases in output. As Frankel, et al. [1980] have shown, the $M B P$ conclusion is correct if money markets do not clear in an ex ante sense, and if prices and interest rates are (at least temporarily) held constant.

On the other hand, if a positive supply shock creates an excess supply of either tradables, $X_{T}>0$, or nontraded goods, $X_{N}>0$ (and if all other markets clear), then we know from (2a) that the balance of payments will turn negative. That is, if either $X_{T}=-B P$ or $X_{N}=-B P$, then clearly an excess'supply of commodities creates a $B P$ deficit. Finally, if the bond market does not clear, then the balance of payments (or exchange rate) effects of

${ }^{24}$ This was first suggested by Mundell [1968], Ch. 9 and explored more fully by Komiya [1969].

${ }^{25}$ See Khan and Willett [1984] for empirical evidence on this issue. 
economic growth depend on whether increases in output and income stimulate bond demand or bond supply more strongly. ${ }^{26}$ All of this suggests that economic growth may affect the $B P$ of different economies in opposite directions, as Miller [1980] finds to be true empirically for five industrial countries.

\section{5 .}

Finally, the general approach to the balance of payments is useful for investigating balance of payments adjustment policies. Again, there is the seemingly obvious conclusion that $B P$ adjustment policies should always focus on the market or markets that are in disequilibrium, and are "causing" the nonzero BP. For example, if interest rate controls allow bond (or credit) markets to be continuously out of equilibrium in developing countries, then the ideal payments adjustment policies are probably those that eliminate the excess supply of bonds (or excess demand for credit). Controls on capital outflows might be a second best policy; but, they now take on a new dimension. That is, to the extent that such controls reduce $X_{A}$, the excess supply of bonds, they decrease the payments deficit.

If commodity market excess supplies are the "cause" of payments deficits, then the deficits can best be eliminated by reducing these excess supplies. Obviously, in such a situation, expenditure reducing policies are inappropriate. Policies that enhance price flexibility may be best. However, tariffs or temporary import restrictions may reduce or eliminate the excess supply of home tradables; hence, such measures may be more desirable than is often thought. 27

Economists have long realized that the Keynesian income-absorption approach to the balance of payments represents a highly simplified model. Nonetheless, the model's basic policy implication is alive and well; expenditure reducing policies have often been forced upon deficit countries by the I.M.F. The general approach to the balance of payments suggests that such measures may be ineffective. Expenditure reducing policies will increase the home excess supplies of tradables, $E_{T}$, and nontraded goods, $E_{N}$, in identity (1). But from (1) and (4b), we know that this in itself has no impact on the balance of payments, because the home budget constraint ensures that $E_{A}$ and/or $E_{m}$ will fall by the same amounts that $E_{T}$ and $E_{N}$ increase. Intuitively, if people spend less, then they must save more in the form of bonds or money. Hence, the left side of ( $4 b)$ is initially unaffected by expenditure reducing policies, and it follows that the BP term on the right of (4b) is also unaffected.

${ }^{26}$ Komiya [1969] assumes that only bond demand responds to increases in income. Patinkin [1966] argues that we have no knowledge of the relative responses of bond demand and bond supply to income variations.

${ }^{27}$ The relevant question is: "do the welfare losses from the tariff exceed the welfare gain from eliminating the excess supply of tradables." Future research should explore this. 
The initial impact of expenditure reducing policies on the $E_{i}$ may lead to changes in income and prices that decrease imports. On the other hand, if a decrease in absorption means an increase in saving, then the capital account may deteriorate. Moreover, the existence of procyclical capital flows implies that the capital account will also worsen if the expenditure reducing policies cause a cyclical downswing. The net effect of all these events appears to be uncertain on a priori grounds. In sum, expenditure reducing policies are not necessarily an effective method for improving the balance of payments.

\section{6.}

Finally, let us briefly consider the effects of exchange rate variations on the balance of payments. One well established conclusion (that came from the $M B P$ ) is that a depreciation of the home currency may exert only a temporary effect on the home balance of payments. The reason is that the depreciation will increase the demand for home goods, and eventually raise home prices enough to neutralize the stimulative effects of the depreciation.

The general approach to the balance of payments suggests that this conclusion holds only if the cause of the payments deficit is not an excess supply of tradables. If the home tradable goods market is in equilibrium when the depreciation occurs, then the $M B P$ conclusion in the previous paragraph should hold, unless some endogenous mechanism reduces total domestic absorption. On the other hand, if an excess supply of home tradables is the "cause" of a payments deficit, then a depreciation can conceivably reduce this excess supply permanently. Moreover, there appears to be no reason why the depreciation must increase home prices proportionately when it occurs in a situation where the home commodity market is initially in excess supply. ${ }^{28}$ Consequently, it may be possible for a depreciation to permanently improve the balance of payments in this case. ${ }^{29}$

\section{7.}

Next, let us change our focus from the period analysis Hahn identity (2a), to the stockflow Hahn identity (7). The latter illustrates Harry Johnson's [1968] important insight that a payments disequilibrium may be composed of inherently temporary stock-adjustment terms such as $K F_{s}$, as well as more permanent flow terms such as the balance of trade and $K F_{f:}$ These types of payments problems must be associated with either inherently temporary

${ }^{28}$ Kenen and Packe [1980] contains an excellent survey of the empirical evidence on how prices react to exchange rate variations.

${ }^{29}$ Niehans [1984] claims that the $M B P$ conclusion holds only if the money market is in equilibrium when the depreciation takes place. If an excess supply of money exists initially, then (according to Niehans) the inflationary consequences of the depreciation will permanently reduce the excess supply of money and the payments deficit. 
stock disequilibria (as when $X_{A}$ and/or $X_{m}$ in (7) are nonzero), or with more permanent flow disequilibria (as when one or more of the $F X_{i}$ are nonzero).

Of particular interest may be the fact that if a payments imbalance is caused by a monetary disequilibrium, then the problem may or may not be inherently temporary. If $X_{m}$ is nonzero then any international flow of money via a payments imbalance will quickly return $X_{m}$ to zero, as the $M B P$ literature has correctly pointed out. However, the problem may not be inherently temporary if it is $F X_{m}$ (the flow excess supply of money) in (7) that is nonzero. In this case the international flow of money via a nonzero $B P$ does not, in itself, eliminate the nonzero flow excess supply of money.

This is not to say that a nonzero $B P$ that is caused by $F X_{m} \neq 0$ will never be eliminated via one $B P$ adjustment mechanism or another. The point is that a disequilibrium in the flow excess supply of money is not eliminated directly via a payments imbalance, as will happen when a stock excess supply or demand for money exists. In brief, a nonzero $B P$ is not necessarily an inherently temporary stock adjustment phenomenon, even in those special cases where the payments imbalance is associated with a money market disequilibrium.

\section{Exchange Rate Theories}

Section 6 uses the Hahn identities, (2), (4b), or (7), to show that many recent theories of exchange rate determination are special cases of a more general approach. This may help to explain why such theories hold up so poorly empirically. ${ }^{30}$ The section also provides insights in the workings of a flexible exchange rate regime, within the context of a general equilibrium framework. The analysis here often utilizes the fact that the ex ante balance of payments (that appears on the right side of the Hahn identities) may be viewed as the ex ante excess supply of foreign exchange, $X_{F X}$, as in (2b), which is rewritten here for convenience.

$$
X_{T}+X_{N}+X_{A}+X_{m} \equiv-X_{F X}
$$

\subsection{The General Approach in Brief}

Assume a period analysis framework with a flexible exchange rate, wherein all international transactions pass through the foreign exchange market, and where each country's money is held only in that country. Then, the exchange rate will move to clear the foreign exchange market, i.e., $X_{F X}=0$, at all times. But $X_{F X}$ will be temporarily nonzero any time

${ }^{30}$ See Khan and Willett [1984] and Meese and Rogoff [1983] for reviews and critiques of recent empirical exchange rate models. 
that one of the market excess supplies for home goods, the $X_{i}$ on the left side of (12), is temporarily nonzero. Therefore, if some shock moves the model away from a position of full equilibrium to an initial state of excess supply for, say, tradables or home bonds, then from (12) we know that the foreign exchange market must temporarily have a negative excess supply, i.e., an excess demand. The home currency will depreciate until $X_{F X}$ is again zero.

This implies that any observed exchange rate movements within a flexible rate system, are always indicative of at least a temporary disequilibrium in one or more markets other than the foreign exchange market. The special case theories of the exchange rate differ with regard to which market or markets are assumed to be out of equilibrium when $X_{F X}$ is nonzero.

\subsection{The Monetary Approach to Exchange Rates}

The assumptions that are needed to generate the single equation monetary approach to the balance of payments are sufficient to obtain the monetary approach to exchange rates, $M E R$, namely that all nonmonetary markets are always in equilibrium. ${ }^{31}$ If so, then (12) tells us that the ex ante excess supply of money always equals minus the $B P$ or minus the excess supply of foreign exchange. Thus, the value for the exchange rate that clears the money market will also clear the foreign exchange market. This implies that it is equally correct to focus on how the exchange rate affects $X_{m}$ or on how the rate affects $X_{F X}$.

Ahtiala [1984] points out that a standard assumptions of the MER are: (a) an infinite interest rate elasticity of international capital flows; and (b) purchasing power parity holds at all times. The former ensures that the home bond market is always in equilibrium, while the latter guarantees instantaneous equilibrium in the commodity market as foreigners automatically buy or sell whatever is needed to keep $E_{T}-B T=X_{T}=0$ in (4b) and (12). Assumptions (a) and (b) in the $M E R$ literature are the equivalent of the small country assumption in the $M B P$ literature.

Recall that the single equation $M B P$ requires more than the extreme small country assumption; it also requires either that nontraded goods do not exist, or that the nontraded goods market is always in equilibrium. The same is true for the MER. If nontraded goods exist, then from (12) not all exchange rates that clear the money market will clear the foreign exchange market, unless, of course, the nontraded goods market always clears instantaneously. If the $X_{N}$ term can be nonzero when all other nonmonetary markets are in equilibrium, then $X_{F X}$ will equal $-\left(X_{N}+X_{m}\right)$. Since all countries have nontraded goods, and

${ }^{31}$ Ahtiala [1984] appears to have deduced this, but he never states it explicitly. 
since it is unlikely that $X_{N} \equiv 0$, it follows that the $M E R$ may not be relevant for any real world countries.

There is no $M E R$ equivalent to the semi-small country macro-model versions of the $M B P$. The reason for this is that models which do not constrain the nonmonetary markets to be in equilibrium for all values of income, prices, interest rates, and exchange rates are obviously allowing such markets to move temporarily out of equilibrium and, hence, to alter exchange rates. Any flexible rate model that contains equilibrium equations for the commodity, bond, and money markets, represents a true general equilibrium macro-model of the exchange rate. Furthermore, the same is true for any flexible rate model that constrains the $B P$ to zero, and that includes equilibrium equations for all but one of the domestic markets. [These last two conclusions follow directly from (12)].

\subsection{The Asset Market Approach}

There are many versions of the asset market approach to the exchange rate, but they all operate within a stock-flow (rather than period analysis) framework. ${ }^{32}$ Hence, instead of (12), the Hahn identity (7) becomes relevant. In general, the exchange rate (and usually the home interest rate) are determined simultaneously within a model that requires $X_{A}=0$ and $X_{m}=0$, i.e., there is "stock" equilibrium in the markets for home bonds and money. From (6b) this implies that the stock-adjustment component of international capital flows, $K F_{s}$, is zero. Therefore, such models explicitly or implicitly assume that $K F_{s}$ in (7) completely dominates the other components of the balance of payments, i.e., $B T+K F_{f} \approx 0$. Thus, $X_{F X}$ is zero when $K F_{s}=0$, and the latter occurs when the stock excess supplies for home money and bonds are zero, i.e., $X_{A}=X_{m}=0$. To the extent that the magnitudes of the current account and/or net flow-adjustment capital flow, $K F_{f}$, are not trivial in magnitude as compared with $K F_{s}$, then the asset market approach may not correctly model exchange rate movements.

\subsection{Keynesian Models}

The traditional Keynesian (or Mundell-Fleming) flexible rate versions of the $I S, L M$, and $B P$ curve models represent true general equilibrium models of the exchange rate, provided that no special assumptions are contained in the models. However, as Ahtiala [1984] correctly points out, Keynesian exchange rate models that assume that monetary policy pegs the interest are not true general equilibrium models. In terms of (12), if the interest rate is

${ }^{32}$ For two examples of the asset market approach, see Dornbusch [1976] and Branson [1980]. An excellent summary and defense of the asset approach appears in Mussa [1983]. Horne [1983] critically reviews the empirical evidence in support of the asset market approach. 
held constant by supplying whatever money people demand, then the $X_{m}$ term is always zero. Thus, $X_{F X}$ and the exchange rate are affected only by disequilibria in one or more other markets. If nontraded goods are ignored, then exogenous shocks affect the exchange rate only via their effects on $X_{T}$ or $X_{A}$, the home tradable goods or bond markets.

\subsection{Future Work}

Future work on exchange rates should concentrate on building a true general equilibrium macro-model of the exchange rate. The Mundell-Fleming models are logically sound, but they are usually constructed either: (a) within a period analysis framework or (b) within a stock-flow framework that ignores the flow excess supplies of bonds and money, $F X_{A}$ and $F X_{m}$ in (7). Hence, the models contain the current account but cannot distinguish between $K F_{s}$ and $K F_{f}$.

There are stock-flow models that allow for $K F_{s}$ as well as a nonzero balance of trade, but such models always ignore $K F_{f}$, the flow-adjustment component of capital flows. This is also true of the partial equilibrium approach of Kouri [1983], wherein the stock adjustment capital flow adjusts endogenously to equal the exogenous current account balance. The rationale for excluding $K F_{f}$ is that such flows are small compared to the stock-adjustment capital flow and the current account, but empirical evidence is ever given to support this.

Some additional topics for future work are to: (1) extend the analysis to two countries simultaneously, i.e., include budget constraints and $\mathrm{Hahn}$ identities for a home and a foreign country;33 (2) develop the commodity market approach to the balance of payments and exchange rates, especially with regard to its implications for government policy; (3) investigate how the conclusions of this essay are affected if a nonmonetary disequilibrium spills over to all markets, and not simply to the money market; (4) allow each country's money supply to be held by residents of other countries, and (5) explore the empirical implications of the general approach to the balance of payments and exchange rates.

\section{Summary and Conclusions}

1. The ex ante balance of payments, $B P$, 'and equivalently, the ex ante excess supply of foreign exchange, $X_{F X}$, are always equal to minus the sum of the ex ante excess supplies for all home goods including money.

2. This means that a payments imbalance must be associated with an ex ante disequili-

${ }^{33}$ Miller [1986] begins this endeavor. 
brium in one or more markets in addition to the foreign exchange market.

3. The underlying reasons for payments imbalances are the same as for individual budget imbalances (which are defined here as net flows of money), namely:

a. initial ex ante money balances are not optimal;

b. not all planned sales are realized;

c. not all planned purchases are realized.

4. Reason (3a) is related to the monetary approach to the balance of payments, $M B P$, which postulates that the only reason for a payments imbalance is an ex ante money market disequilibrium, i.e., $X_{m} \equiv-B P$, where $X_{m}$ is the ex ante excess supply of money. This, of course, is only one of many possible special cases.

5. The $M B P$ is defined here to include all models that constrain the balance of payments to equal the ex ante disequilibrium in the money market. This is sometimes made explicit, but often such a constraint is simply implicit, due to the fact that the money supply term is defined to include the current period's flow of international reserves.

6. The $M B P$ has appeared in single equation (money market equilibrium) models as well as in macro-models of both the small country and semi-small country variety. In the first two, all nonmonetary markets are always in equilibrium via the extreme small country assumption (which may be approximated via the assumption that PPP always holds, and that capital flows have an infinite interest elasticity). In the last, the model usually includes equilibrium equations for all nonmonetary markets.

7. The single equation and small country macro-model versions of the $M B P$ do not hold (i.e., the balance of payments is not always determined by the money market disequilibrium) if nontraded goods exist, unless this market always clears instantaneously.

8. The $M B P$ 's fundamental conclusion, i.e., that the disequilibrium in the money market causes the balance of payments to be nonzero, does not hold in all situations, even if the model's assumptions ensure that $X_{m} \equiv-B P$. The direction of causation depends on the type of shock that occurs:

a. in the strong $M B P$, a nonzero $X_{m}$ causes the $B P$ to change; this happens only when an exogenous shock initially affects the money market but not the balance of payments;

b. in the weak $M B P$, a nonzero $X_{m}$ will eventually be associated with a $B P$ of equal magnitude, but the cause-effect relationship may be reversed; this occurs when a shock initially affects only the balance of payments.

9. The reasons for individual budget imbalances given by $3 \mathrm{~b}$ and $3 \mathrm{c}$ above relate to the traditional Keynesian models of the balance of payments, $K B P$, that include simultaneous equilibrium in the commodity and money markets, but the possibility of a nonzero $B P$. 
The Keynesian models implicitly assume that the bond market does not clear, and that the excess supply of bonds, $X_{A}$, equals minus the balance of payments.

10. Conclusion $\# 9$ suggests that the $K B P$ may be less relevant in advanced economies that have well developed bond markets, and more relevant in developing countries, especially those wherein the government pegs the interest rate below its equilibrium rate. If the latter creates an excess supply of bonds, then conclusion $\# 9$ suggests that such countries will have chronic payments deficits.

11. The general approach to the balance of payments suggests that there are other theories of the $B P$ that have yet to be developed. Such theories will equate the $B P$ with the disequilibrium in either the traded or nontraded goods markets. For example, an excess supply of tradables will be associated with a $B P$ deficit. Such a theory is likely to be relevant in countries when export shocks are the primary cause of payments imbalances.

12. The $K B P$ may be applicable to advanced economies if the "bond" market is interpreted broadly to include all nonmonetary assets, such as land, tangible capital goods, and houses, since it is conceivable that the markets for these assets may clear more slowly than for bonds, as typically defined.

13. In all special case models of the balance of payments wherein the $B P$ is assumed to equal the disequilibrium in one particular market, people may willingly give up or accept the money associated with a payments imbalance, even though the money market is initially in equilibrium. The implicit assumption is that a disequilibrium in a nonmonetary market spills over completely to the money market, and alters the demand for money. Thus, the initially zero primary excess supply for money plus the spillover effect create a nonzero secondary excess supply of money. It is incorrect, however, to treat these secondary excess supplies or demands for money as the "cause" of payments imbalances.

14. In Friedman's closed econcmy neo-quantity theory, the government determines the nominal quantity of money, and the money market clears very slowly as people try to spend any unwanted money; by doing so, they bid up commodity prices (and thereby reduce the real money supply). Within such a world, the money market might be a good candidate for the nonclearing market that always determines the $B P$. However, the $M B P$ may not be relevant if the nominal quantity of money quickly changes endogenously to equal money demand as when: (a) people switch into or out of demand deposits as their demand for money changes; or (b) the central bank focuses monetary policy on interest rates.

15. Exogenous decreases in foreign demand for home exports ( $B T$ falls) or bonds ( $K F$ falls) lead to a payments deficit that is accompanied by:

a. an excess supply of home tradables when $B T$ falls; thus, the yet to be developed "commodity market approach" to the $B P$ is relevant; 
b. an excess supply of home bonds when $K F$ falls (as during speculative periods); thus, the Keynesian approach to the $B P$ is relevant.

16. Economic growth via an exogenous increase in the supply of commodities will have no effect on the $B P$ if all markets remain in equilibrium. The effect of such growth on the $B P$ may depend on which market is assumed not to clear:

a. if the money market does not clear, then the growth in income will, in itself create an excess demand for money; this generates the $M B P$ conclusion that growth leads to a payments surplus;

b. if the commodity markets do not clear initially, then growth in itself is apt to create an excess supply of commodities (if the propensity to absorb is less than unity); in this case, growth causes a payments deficit;

c. if the bond market does not clear, the $K B P$, then the results depend on whether growth stimulates bond supply or bond demand more; if bond supply increases more, then a $B P$ deficit occurs.

17. All open economy models that generate a nonzero balance of payments in response to monetary or fiscal policy, have implicity assumed that one or more markets do not clear. If all markets clear in an ex ante sense, then monetary and/or fiscal policy have no effect on the balance of payments.

18. The $K B P$ generates the well known conclusion that a bond financed fiscal expansion may improve or deteriorate the balance of payments, depending on whether the $L M$ curve is steeper or flatter than the $B P$ curve. Our conclusion \# 9 (that the $K B P$ implicitly assumes that the bond market disequilibrium determines the $B P$ ) privides a fresh insight into this matter. If a bond financed fiscal expansion drives the bond market out of equilibrium, it seems likely that an excess supply of bonds will exist, at least initially. This, and conclusion $\# 9$, imply that a bond financed fiscal expansion may lead to a payments deficit within the $K B P$.

19. Balance of payments adjustment policies should focus on the market that is out of equilibrium and that is "causing" the $B P$ problems. This suggests that:

a. the elimination of interest rate controls may be the best adjustment policy in many developing countries;

b. if a payments deficit is "caused" by an excess supply of tradables, then tariffs or a currency depreciation might permanently improve the balance of payments;

c. expenditure reducing policies may be appropriate if a payments deficit is caused by an excess supply of bonds or of money; however, such measures may worsen a balance of payments deficit that is associated with an excess supply of commodities.

20. Conclusion \#19b differs from the conventional wisdom idea that a tariff or cur- 
rency depreciation will have only a temporary effect on the balance of payments, because the conventional wisdom assumes that commodity markets are always in equilibrium. Thus, any expenditure switching policies in favor of home goods will lead to higher home prices, which wipe away the positive effects from the tariff or the depreciation. However, if the "cause" of a payments deficit is an excess supply of tradables, and if tariffs or a depreciation can eliminate this excess supply, then there is no a priori reason why home prices should rise proportionately with the tariff or depreciation.

21. Within a stock-flow model, a nonzero balance of payments can arise either because of a:

a. disequilibrium in the stock excess supply of bonds or money, which leads to a nonzero stock-adjustment capital flow;

b. disequilibrium in the flow excess supplies of commodities, bonds, or money,... which creates a nonzero current account and/or flow-adjustment capital flow.

Thus, a payments deficit is not always an inherently temporary stock adjustment phenomenon!

22. Within a flexible exchange rate system, any fluctuation in the exchange rate implies that at least one market (in addition to the foreign exchange market) has been out of equilibrium.

23. Many of the theories of exchange rate determination are special cases of a general theory:

a. the monetary approach to exchange rates, $M E R$, assumes that $X_{m} \equiv-X_{F X}$, i.e., an equilibrium in the money market, $X_{m}=0$, always implies that the foreign exchange market is in equilibrium, $X_{F X}=0$. Hence, the $M E R$ implicitly or explicitly assumes that all nonmonetary markets are always in equilibrium; this is often accomplished via the assumptions of: (i) continuous PPP ... to clear the traded goods market; (ii) an infinite interest elasticity of international capital flows ... which clears the bond market; in addition, the $M E R$ must assume either that nontraded goods do not exist or that the nontraded goods market always clears instantaneously;

b. the asset market approach to exchange rates operates within a stock-flow framework and assumes that stock-adjustment capital flows dominate the movements in the exchange rate; if all flow magnitudes (such as the current account and flowadjustment capital flow) are trivial in magnitude, then the balance of payments (or the foreign exchange market excess supply) equals the sum of the stock excess supplies for bonds and money; thus, a simultaneous equilibrium in these two markets ensures an equilibrium in the foreign exchange market; 
c. the Keynesian models which assume that monetary policy pegs the interest rate are implicitly assuming that the exchange rate is determined in the commsdity and bond markets.

24. The period analysis Keynesian flexible rate models that assume that monetary policy focuses on controlling the nominal money supply are, indeed, true general equilibrium macro-models of the exchange rate. They, however, suffer from the limitations of a discrete time model in that they cannot explore the complexities of stock versus flow adjustments and both stock-adjustment capital flows, $K F_{s}$, as well as flow-adjustment capital flows, $K F_{f}$. Finally stock-flow Keynesian models usually ignore the $K F_{f}$ component of international capital flows.

\section{Appendix A: Derivation of (1), (2a), and (2b) \\ The Four Good, Period Analysis, Sectoral Budget Constraints}

A1. Private Sector:

$$
\left(Y_{T}+Y_{N}-T_{X}\right)+\left[\left(D_{0}+R_{0}\right)+\left(A_{0}-H_{d j}^{*}+H_{f 0}\right)\right]+\Delta A_{b} \equiv C_{T}+C_{N}+I_{T}+I N+L+H
$$

A2. Government Sector: Treasury plus Central Bank:

$$
T_{X}+(\Delta R+\Delta D)+A_{g} \equiv G_{T}+G_{N}+\Delta R
$$

A3. Exchange Stabilization Fund: (ESF):

$$
\Delta R \equiv S_{F X}-D_{F X} \equiv B T+K F
$$

\section{Definitions}

$Y_{T}, Y_{N} \quad=$ output of tradables and non-tradables

$T_{X} \quad=$ net taxes

$D_{0}, \Delta D \quad=$ initial value and changes in the domestic assets of the Central Bank

$R_{0} \Delta R \quad=$ initial value and changes in the international reserves held by the Central Bank

$A_{0}, \Delta A_{b}+\Delta A_{g} \quad=$ initial stock of home bonds and changes in the supply of bonds by business and government

$C_{T}, C_{N}, I_{T}$

$I_{N}, G_{T}, G_{N}$

= consumption, investment and government demands for tradables and non-tradables

$H_{d 0}^{*}$

$H_{f 0}$

$=$ initial foreign holdings of domestic bonds

$L, H$

$=$ initial home holdings of foreign bonds

$S_{F X}, D_{F X}$

$B T, K F$

=home demand for money and bonds

= supply and demand for foreign exchange

= balance of trade and net capital flow

\section{Discussion}

1. Each budget constraint has ex ante sources of funds on the left, and uses for funds on the right. All magnitudes are in dollars with prices and exchange rates fixed at unity.

2. The large bracketed term on the $l$.h.s. of (A1) is initial wealth.

3. The government budget constraint embodies the fact that the purchase (by the central bank/treasury) of international reserves, $\Delta R>0$, from the ESF is both a use for funds (on the r.h.s. of A2) and a source of funds when $\Delta R$ is monetized (on the l.h.s. of A2). 
4. The ESF is assumed to sell dollars and buy international reserves in order to peg the exchange rate when $S_{F X}$ exceeds $D_{F X}$. All ESF purchases of $R$ are sold immediately (for dollars) to the government (central bank/treasury). Thus, a payments surplus creates an outflow of dollars for the ESF on the r.h.s., and on inflow of dollars on the l.h.s., i.e., a $\Delta R>0$ refers to an increase in the $R$ held by the central bank/ treasury and not by the E.S.F.

5. All budget constraints and definitions ignore the international flow of interest payments.

\section{Derivations}

1) The sum of (A1) and (A2) yields (1) in the text, where:

$$
\begin{aligned}
& E_{T} \equiv Y_{T}-C_{T}-I_{T}-G_{T} \\
& E_{N} \equiv Y_{N}-C_{N}-I_{N}-G_{N} \\
& E_{A} \equiv\left[\left(A_{0}+\Delta A_{b}+\Delta A_{g}+H_{f 0}-H_{b b}^{*}-H\right]\right. \\
& E_{m} \equiv D_{0}+R_{0}+\Delta D-L
\end{aligned}
$$

2) The sum of (A1), (A2), and (A3) yields (2a) or (2b) in the text, where

$$
\begin{aligned}
& X_{T} \equiv E_{T}-B T \\
& X_{N} \equiv E_{N} \\
& X_{A} \equiv E_{A}-K F \\
& X_{m} \equiv E_{m} \\
& X_{F X} \equiv S_{F X}-D_{F X} \equiv B P
\end{aligned}
$$

Appendix B: Derivation of (5a), (5b), (6a), (6b), (7)

The Four Good, Stock-Flow Analysis, Sectoral Budget Constraints

BI. Private Sector:

a) Flows: $\left(Y_{T}+Y_{N}-T_{X}\right)+\dot{A}_{b} \equiv C_{T}+C_{N}+I_{T}+I_{N}+\dot{L}+\dot{H}$

b) Stocks: $D_{0}+R_{0}+A_{0}-H_{d 0}^{*}+H_{f 0} \equiv L+H$

B2. Government Sector (central bank plus treasury)
a) Flows: $T_{X}+\dot{D}+\dot{R}+\dot{A}_{g} \equiv G_{T}+G_{N}+\dot{R}$
b) Stocks: none

B3. Exchange Stabilization Fund (ESF):

a) Flows: $\dot{R} \equiv B T+' K F_{f}$

b) Stocks: $\Delta R \equiv \Delta H_{d}^{*}-\Delta H_{f}$

\section{Definitions and Derivations}

1. All variables are defined as in Appendix A. and the text, with a dot above a variable representing flows per unit of time, and with:

$\Delta H_{f}, \Delta H_{d}^{*}=$ changes in stock demands for foreign bonds by home residents, and in foreign demand for home bonds, respectively

2. The sum of B1a and B2a yields (5a) in the text, where:

3. Identity $\mathrm{B} 1 \mathrm{~b}$ is $(5 \mathrm{~b})$ in the text, where:

$$
\begin{aligned}
& F E_{T} \equiv Y_{T}-C_{T}-I_{T}-G_{T} \\
& F E_{N} \equiv Y_{N}-C_{N}-I_{N}-G_{N} \\
& E F_{A} \equiv \dot{A}_{b}+\dot{A}_{g}-\dot{H} \\
& F E_{m} \equiv \dot{D}-\dot{L}
\end{aligned}
$$

$$
\begin{aligned}
& E_{A} \equiv A_{0}-H_{d 0}^{*}+H_{f 0}-H \\
& E_{m} \equiv D_{0}+R_{0}-L
\end{aligned}
$$

4. The sum of B1a, B2a, and B3a yields (6a) in the text, where:

$$
\begin{aligned}
& F X_{T} \equiv F E_{T}-B T \\
& F X_{N} \equiv F E_{N} \\
& F X_{A} \equiv F E_{A}-K F \\
& F X_{m} \equiv F E_{m}
\end{aligned}
$$


5. Summing B1b, and B3b and multiplying through by $\phi$ yields (6b) in the text, where:

$$
\begin{aligned}
& \phi X_{A} \equiv \phi\left[E_{A}-\left(\Delta H^{*}-\Delta H_{f}\right)\right] \\
& \phi X_{m} \equiv \phi E_{m} \\
& K F_{s} \equiv \phi \Delta R
\end{aligned}
$$

\section{Appendix C: The Income-Absorption Approach}

We know from (10) in the text that $X_{T}=0$ implies:

$$
X_{A}=-B T,
$$

the magnitude of the balance of trade equals the disequilibrium in the home bond market. Since bonds are not traded internationally, it follows that $X_{A} \equiv E_{A}$, if $H_{f 0}$ and $H_{d 0}^{*}$ (each country's initial holdings of the other country's bonds) are equal to zero. This gives:

$$
X_{A} \equiv E_{A} \equiv\left[\left(A_{0}+\Delta A_{b}+\Delta A_{g}-H\right],\right.
$$

where, for review, $A_{0}$ is the initial quantity of domestic bonds, $\Delta A_{b}$ equals business bonds for investment, and $\Delta A_{g}$ equals the change in government bonds outstanding.

All new business bonds, $\Delta A_{b}$, are used to finance investment. Also, since total end of period home demand for bonds, $H$, equals demand in the previous period $H_{-1}$, plus that portion of saving, $S$, thatgoes toward the purchase of bonds $(\mathrm{C} 2)$ can be rewritten as:

$$
X_{A} \equiv E_{A} \equiv\left[\left(A_{0}+I_{T}+\Delta A_{g}\right)-\left(H_{-1}+S-\Delta L\right)\right],
$$

where $\Delta L$ is that portion of saving going into money balances. If the bond market was in equilibrium in the previous period, (i.e., $A_{0}-H_{-1}=0$ ), and if we use the government budget constraint $T x+\Delta D+\Delta A_{g}$ $\equiv G$ to solve for $\Delta A_{g}$, then (C3) becomes:

$$
X_{A} \equiv E_{A} \equiv\left[I_{T}+\left(G_{T}-T x-\Delta D\right)-\left(Y_{T}-C_{T}-T x-\Delta L\right)\right],
$$

where use is made of the definition of saving. Since the government is pegging the interest rate by setting $\Delta D$ equal to $\Delta L$, we obtain:

$$
X_{A} \equiv E_{A} \equiv\left[\left(G_{T}+I_{T}+C_{T}\right)-Y_{T} \equiv\left[A b_{T}-Y_{T}\right]\right.
$$

The excess supply of home bonds equals absorption minus income within the simple income-absorption framework.

\section{References}

Alexander, Sidney S., "Effects of a Devaluation: A Simplified Synthesis of Elasticities and Absorption Approaches," American Economic Review, March 1959, 49, pp. 22-42.

Allen, Polly Reynolds and Peter B. Kenen, Asset Markets and Economic Integration: A Synthesis, New York: Cambridge University Press, 1980.

Ahtiala, Pekka, "A Synthesis of the Macroeconomic Approaches To Exchange Rate Determination," European Economic Review, Vol. 24, March 1984, 24, pp. 117-136.

Branson, William H., Financial Capital Flows in the U.S. Balance of Payments, Amsterdam, North-Holland, 1968.

Branson, William H., "Asset Markets and Relative Prices in Exchange Rate Determination," Reprints in International Finance, Princeton University, No. 20, June 1980.

Buiter, Willem H., and Jonathan Eaton, "Keynesian Balance of Payments Models: "Comment," American Economic Review, Vol. 71, September 1981, 71. pp. 784-795.

Chen, Chan-Nan, "IS, LM, BT, and a Simplified Synthesis of the Elasticity, Absorption, and Monetary 
Approaches to Devaluation," Southern Economic Journal, July 1975, 42, pp. 132-136.

Clower, Robert W., "The Keynesian Counterrevolution: A Theoretical Appraisal," in F. H. Hahn and F. P. R. Breckling, eds., The Theory of Interest Rates, London: St. Martin's Press, 1965.

Clower, Robert W., "A Reconsideration of the Microfoundations of Monetary Theory," Western Economic Journal, 1967, 6.

Cohen, Jacob, "The Money Supply Process: How Much Progress Since C. A. Phillips' Bank Credit?" Kredit and Kapital, Vo. 17, January 1984, 17, pp. 333-351.

Deardorff, Alan V., "A Framework for Analysis in International Macroeconomics," Welwwirtschaftliches Archiv (1977).

Deardorff, Alan V., "Keynesian Balance of Payments Models: Comment," American Economic Review, September 1981, 71, pp. 774-777.

Dornbusch, Rudiger, "Notes on Growth and the Balance of Payments," The Canadian Journal of Economics, August 1974, pp. 389-395.

Dornbusch, Rudiger, "Expectations and Exchange Rate Dynamics," Journal of Political Economy, December 1976, 84, pp. 1161-1176.

Dornbusch, Rudiger, Open Economy Macroeconomics, New York: Basic Books, 1980.

Ferguson, J. David and William R. Hart, "The Implications of Spillover for the Design of Monetary Policy: An Empirical Analysis of Income and Price Determination in Non-Clearing Markets," American Economic Review, December 1985, 75, pp. 1133-1142.

Fleming, J. Marcus, "Domestic Financial Policies Under Fixed and Under Floating Exchange Rates," I.M.F. Staff Papers, 1962, 9, p. 369.

Foley, Duncan K., "On Two Specifications of Asset Equilibrium in Macroeconomic Models," Journal of Political Economy, April 1975, 83, pp. 303-324.

Frenkel, Jacob A., Thorvaldur Gylfason, and John F. Helliwell, "A Synthesis of Monetary and Keynesian Approaches to Short Run Balance of Payments Theory," Economic Journal, September 1980, 90, pp. 582-592.

Frenkel, Jacob A. and Harry G. Johnson, The Monetary Approach to the Balance of Payments, Toronto: University of Toronto Press, 1976.

Gylfason, Thorvaldur and John F. Helliwell, "A Synthesis of Keynesian, Monetary, and Portfolio Approaches to Flexible Exchange Rates," N.B.E.R. Working Paper No. 949, July 1982.

Grossman, Herschel I., "Money, Interest, and Prices in Market Disequilibrium," Journal of Political Economy, September/October 1971, 79, pp. 943-961.

Hahn, Frank H., "The Monetary Approach to the Balance of Payments," Journal of International Economics, 1977, 7, pp. 231-249.

Horne, Jocelyn, "The Asset Market Model of the Balance of Payments and the Exchange Rate: A Survey of Empirical Evidence," Journal of International Money and Finance, August 1983, 2, pp. 89-109.

International Monetary Fund Research Department, The Exchange Rate System: Lessons of the Past and Options for the Future, Washington, D.C., I.M.F., July 1984.

Johnson, Harry G., "Towards a General Theory of the Balance of Payments," reprinted in A.E.A. Readings in International Economics, Homewood, Ill: Irwin, 1968.

Johnson, Harry G., "The Monetary Approach to the Balance of Payments,"'reprinted in his Further Essays in Monetary Economics, London: Allen and Unwin, 1972.

Johnson, Harry G., "Some Aspects of the Theory of Economic Policy in a World of Capital Mobility," in Essays in Honor of Marco Fanno, 1966.

Kenen, Peter B. and Clare Pack, Exchange Rates, Domestic Prices, and the Adjustment Process, Occasional Papers No. 1, New York: Group of Thirty, 1980.

Khan, Wasseam and Thomas D. Willett, "The Monetary Approach to Exchange Rates: A Review of Recent Empirical Studies,” Kredit and Kapital, 1984.

Kierzkowwski, Henryk, "Towards the Integration of Balance of Payments Theories," Schweizerische 
Zeitschrift fur Bolkswitrschaft, No. 2, 1979.

Komiya, Ryutaro, "Economic Growth and the Balance of Payments: A Monetary Approach," Journal of Political Economy, January/February 1969, 77, pp. 35-48.

Kouri, Pentti J. K., "Balance of Payments and the Foreign Exchange Market: A Dynamic Partial Equilibrium Model," in Economic Independence and Flexible Exchange Rates, ed. by J. S. Bhandari and B. H. Putnam, Cambridge: MIT Press, 1983.

Kuska, Edward A., "On the Almost Total Inadequacy of Keynesian Balance of Payments Theory," American Economic Review, September 1978, 68, pp. 659-670.

Kuska, Edward A., "On the Adequacy or Inadequacy of Keynesian Balance of Payments Theory: A Reply," American Economic Review, Septemter 1982, 72, pp. 887-898.

Massourakis, Michael, "The Monetary Approach to the Balance of Payments Under a Generalized Exchange Rate Regime as Applied to the Small Open Eccnomy: Theory and Evidence," I.M.F. Working Faper, May 1983.

Me:se, Richard A., and Kenneth Rogoff, "Empirical Exchange Rate Models of the Seventies: Dot hey Fit Out of Sample," Journal of Internaticnal Economics, Fetruary 1983, 14, pp. 3-24.

Miller, Norman C., "Monetary vs. Traditional Approaches to the Balance of Payments," American Economic Review, May 1978, 68, pp. 406-411.

Miller, Norman C., "Offset and Growth Coefficients for Five Industrial Countries," Review of Economics and Statistics, August 1980, 62, pp. 329-338.

Miller, Norman C., "The Adequacy of Keynesian Models of the Balance-of-Payments," American Economic Review, September 1981, 71, pp. 778-783.

Miller, Norman C., "The Structure of Open Economy Macro-Models," Journal of International Money and Finance, March 1986, 5, pp. 75-89.

Miller, Norman C. and Marina V. Whitman, "A Mean-Variance Analysis of U.S. Long Term Portfolio Foreign Investment," Quarterly Journal of Economics, May 1970, 85, pp. 175-196.

Muellbauer, John and Richard Portes, "Macroeccnsmic Models with Quantity Rationing," Economic Journal, December 1978, 88, pp. 788-821.

Mundell, Robert, International Economics, NY: Macmillan, 1968, esp. Chs. 10 \& 15.

Mussa, Michael, "Empirical Regularities in the Behavior of Exchange Rates and Theories of the Foreign Exchange Market," In Theory Policy, Institutions: Papers from the Carnegie-Rochester Conference on Public Policy, ed. by K. Brunner and A. Meltzer, Amsterdam: North-Holland, 1983, pp. 165-213.

Neary, J. Peter, "Nontraded Goods and the Balance of Trade in a Neo-Keynesian Temporary Equilibrium," Quarterly Journal of Economics, November 1980, 95, pp. 403-429.

Miehans, Jurg, International Monetary Economics, Baltimore: Johns Hopkins University Press, 1984.

Ott, David J., Affiat F. Ott, and Jang H. Yoo, Macroeconomic Theory, New York: McGraw Hill, 1975.

Patinkin, Don, Money, Interest and Prices, 2nd ed., Harper-Row, 1965.

Rabin, Alan A., "A Note on the Link Between Balance of Payments Disequilibrium and the Excess Demand for Money," Southern Economic Journal, April 1979, 45, pp. 1233-1238.

Rabin, Alan A., and Leland B. Yeager, "Monetary Approaches to the Balance-of-Payments and Exchange Rates," in Economic Perspectives, ed. by Maurice B. Ballabon, London: Harwood, 1979, pp. 173-201.

Rabin, Alan A., and Leland B. Yeager, Monetary Approaches to the Balance of Payments and Exchange Rates, Essays in International Finance, No. 148, November 1983, Princeton University Press.

Williamson, John, The Open Economy and the World Economy, New York: Basic Books, 1983. 